\title{
PPP investment in land passenger transportation infrastructure: exploratory comments regarding its effects on competition
}

\author{
Joaquim Aragão'; Enilson Santos²; \\ Rômulo Orrico Filho ${ }^{3}$; Anísio Brasileiro ${ }^{4}$
}

\begin{abstract}
This paper aims to propose an analytical framework devoted to understand competition moments and their respective features in different stages of a land passenger transport infrastructure investment undertaking. As it will be argued, competitive processes arise well before the procurement stage which is considered the main competitive instance in the undertaking: the setup of investment policies and the choice of the specific projects are already subject of political pressures, which are competitive struggles between relevant stakeholders, some of which will take part in the final procurement stage. And even after this stage the competition does not cease, as competitive services shall challenge the undertaking. Also, the external benefits of the investment gives rise to competition between different stakeholders, for instance in the real estate market. The paper explains the different stages of competition and illustrates the outcomes in a selected study case.
\end{abstract}

Resumo: O presente artigo visa a propor um quadro analítico para estudar os diferentes momentos de competição e suas características específicas em empreendimentos de infra-estrutura de transporte terrestre de passageiros. Como é argüido, os processos competitivos emergem bem antes do estágio licitatório, o qual é considerado a principal instância de competição nesse tipo de empreendimento. O estabelecimento de políticas de investimento e a escolha de projetos específicos já estão sujeitas a pressões políticas que refletem processos competitivos entre atores interessados, entre os quais alguns potenciais participantes da futura licitação. E, mesmo depois desse estágio, a competição não cessa, uma vez que serviços competitivos de transporte irão desafiar permanentemente o empreendimento. Também, benefícios externos do investimento dão origem à competição entre diferentes interessados, por exemplo, no mercado imobiliário. O artigo examina os diferentes estágios de competição e ilustra os resultados por meio de um estudo de caso selecionado.

\section{INTRODUCTION}

The impact of new infrastructure investment on market competition is a research issue that deserves a deeper analysis, as this investment may imply major transformations in mobility patterns and also in the regulatory and competition policy, especially when a totally new quality pattern is introduced as a consequence of a strategic plan for mobility and land use development. In a more concrete way, new investments in passenger transport infrastructure may have diverse implications. Firstly, they may attract existing demand from competing systems and services, as well as new demand in the course of modification of land use patterns. Secondly, they impose modifications to the operating market as they introduce new regulations, actors and contracts. When private infrastructure investment is involved, the respective huge risks may even force the government to super-protect the investors from competition and market risks in gen-

\footnotetext{
${ }^{1}$ Joaquim Aragão, Universidade de Brasília. Brasília, DF, Brasil (e-mail: aragao@unb.br).

${ }^{2}$ Enilson Santos, Universidade Federal do Rio Grande do Norte. Natal, RN, Brasil. (e-mail: emsantos@ct.ufrn.br).

${ }^{3}$ Rômulo Orrico Filho, Universidade Federal do Rio de Janeiro. Rio de Janeiro, RJ, Brasil (e-mail: Rômulo@pet.coppe.ufrj.br).

${ }^{4}$ Anisio Brasileiro, Universidade Federal de Pernambuco. Recife, PE, Brasil. (e-mail: anisiobfd@hotmail.com).
}

Este artigo é parte de TRANSPORTES, volume XIV, número 2, dezembro de 2006. ISSN: 1415-7713. eral.

The present contribution has as its central aim to develop, in a still very preliminary stage, a general framework for understanding the competition processes in situations where new infrastructure investment for land passenger transportation is enabled by the participation of private capital. These competition processes are not simple nor linear, as it will be argued along the paper: they are not limited to the moment when the new infrastructure alters or even distorts (in the course of necessary protection measures by the government) the existing market. Actually, the different decision stages that follow along the whole process (policy, regulatory strategy, strategic planning, project decision and project design, procurement and execution) are competition processes, as competition arises e.g. between the different investment and regulation strategies, between the more concrete design options, between the concessionaires in spe, and only then at last between the transport operators (and also, we add, between the beneficiaries of the infrastructure investment, mainly by the competition in the real estate market). In all these spheres of competition, different constellations of actors try to impose the decision alternatives that best fit to their respective interests.

Based on this framework proposal, the present contribution stresses the need for analyzing the competition process in the event of infrastructure investment 
in land passenger transport in a broader sense that includes these different stages, as a sole focus on competition on the service market once the new infrastructure is operating will not be sufficient to explain the actually occurring decision processes.

Initially, the different moments of competition in a PPP project with respect to land passenger transportation are discussed and systemized.

\section{COMPETITION PROCESSES IN PPP PROJECTS IN LAND PASSENGER TRANSPORTATION INFRASTRUCTURE}

The general theory on competition has been developed by different authors, whereby the scripts by Porter (1998) have deserved a particular prestige. The framework adopted by this author focus on five different forces that drive the competition in a given industry. Following Porter, they are:

- The direct competition between the firms within an industry;

- The menace of competition by eventual new entrants;

- The bargaining power of costumers;

- The bargaining power of suppliers;

- The menace of substitute goods.

Evidently, the simple transference of this framework, which had been set up for goods and services delivered in a free market, is not straight forward for markets which are strongly regulated by a government, mainly due to prevailing characteristics of natural monopoly. This observation may apply especially to heavy infrastructure projects which are contracted by the Public Administration to the private sector by means of public-private partnerships.

Within the literature, the competition issue has basically focused on the competition for and in the market between operators, but competition between infrastructure projects has been left aside. The main topics currently discussed have been dealing with the competition policy and its respective economic and social objectives and targets, with deregulation processes and competitive tendering procedures, with the design of the respective contracts, with other regulatory instruments which aim to assure competition and efficiency gains (Preston, 2005; Nash and Walters, 2005). At most, when dealing with funding issues, costly systems have been pointed out as a hindrance to competition.

However, when the business to be contracted is not limited to the simple delivery of transportation services but includes also the construction of infrastructure, the analytical approach for this kind of competition have to be broadened. In such case, the framework to be adopted has to take in account the concrete competition processes and the respective interfering actors along a chain of different stages, as follows:

a) The stage of definition of the general regulatory strategy and of the legal framework for public investments: here, diverging political orientations try to impose the role and limits of the action of the Public Administration. At this stage the relevant actors are the parties and respective supporting political organizations as unions, syndicates, chambers, but also prominent intellectuals, the press and other actors with relevant influence on the public opinion. Some international actors are also to be remembered as proponent forces, as the multilateral agencies (IRDB, IMF, $\mathrm{ADB}$ ) and regional supranational organizations (eg. European Union).With respect to the still national scene, the relationships between parties and their programs, which need not to be too much tied to their original ideology (as the programs may reflect also electoral strategies and opportunism, which are dependent on the current dominant political environment) are a core issue for this level of analysis.

b) The stage of definition of the actual projects to be gone forward with by the sector policies: here not solely the government agents give the cards but also the political actors in their struggle for benefits for their constituencies, and beyond this the main actors and representatives from the financial sector, as well from the manufacturing and construction industries in their search for new market opportunities;

c) The stage of the selection of the projects for their inclusion into the PPP Program: the same actors listed in b) are relevant, but in a minor degree, as their main interest is to put the project in which they hold a stake on to the governmental agenda, and less the concrete form of their contractual framework;

d) The stage of the specificities of the project, where the competition between consultancy firms is stronger; but also different social agents may interfere by their criticisms into the concrete project design (we will omit this stage in the further analysis);

e) The stage of the selection and contract procedures: here a competition process between supplying manufacturers, construction firms, and actors from the financial market may be observed when the consortia are to be set up. Also, the government will court investors in the international PPP market, where different countries are competing for their attention. Finally, there will take place the main competition process which is the procurement procedure itself;

f) The stage of the competition in the transportation market: at this stage the different suppliers of transportation services (not to oversee are the taxicab and coach operators) and also the individual transport and all the industries which support it (car manufacturers, the commercial exploiters of garages and parking lots, car hire agencies, maintenance workshops and the re- 
spective delegates in politics) are to be inserted;

g) The competition for the benefits of the infrastructure investment: here the public planning agents, the real estate industry, the commerce and the manufacturing industries and also the users of the infrastructure are trying to get their place in the sun.

In markets dominated by natural monopoly phenomena, the competition is said to happen for the market, and less in the market. However, the framework explained here, especially with respect to the stages a) to d), suggests the introduction of the concept of competition before the market, where competition processes take place and alliances are built in order to influence the construction of the competition rules and even the design of the very subject of the market dispute which is the infrastructure project. Therefore, it has to be analyzed with more detail on how the competition processes before the market influence the competition processed for (procurement) and in the market (operation): one may for instance detect that the competition before the market eliminates or reduces drastically the possibilities of the other subsequent competition processes, especially when we are dealing with infrastructure projects. Especially in transportation projects we may detect some confusion between subjects which belong to the transportation industry (including the supplying of equipments and installations) and other markets that are influenced directly or indirectly by this industry complex (real estate, consultancy, among others).

But this interference and confusion may vary from subject to subject, even within the transportation industry, and depend from the concrete local context. For instance, the toll road contracts in infrastructure concessions are in the rule subject to the competition from other toll-free roads or even from railroads and air transportation. In some developing countries, where the road network is thin and the single roads given to concession have no actual competitors, the natural monopoly concept applies fully. In some urban transit projects, the contracted rail investors may impose their control over potentially concurrent bus services; in other cities, this is either politically or operationally impossible.

On the basis of all this multi-stage competition process, the present contribution aims to discuss, at a preliminary level, each of these moments, searching the proper analytical tools for each stage and bringing in case examples.

\subsection{Competition for the definition of regulatory strategies}

The end of the Welfare State and the reinforcement of the liberal approach have provoked already well discussed changes in the forms of provision of essential facilities. The voluntary opening of playrooms for private investment but also a higher awareness for efficiency gains in the supply of public services and for a better use of the public finances has been the main drivers of this process. All this movement has as theoretical byproduct the development of concepts and tools of the Economics of Regulation, which backed deregulation and competition policies, competitive tendering procedures and, more recently, the publicprivate partnerships. But the involvement of the private industry into the provision of essential facilities has also another historical origin than the fight for more efficiency, which is the lack of financial resources for new investment and even for the maintenance of the existing infrastructures. And both motivations, struggle for efficiency or search for financial resources, may imply distinct strategies for the insertion of private capital. A third force has also influenced the 'regulatory revolution' in some countries which is the pressure from multilateral or supranational agencies (see above).

All this background is already well discussed in academic literature (see, for example, the Thredbo Conference Series) and is recalled here as the starting point for the discussion of the first competition level to be considered. This competition level between regulatory strategies has begun with the struggle between ideas and the programs of political parties but also with the financial problems of the governments.

With respect to the struggle between ideologies and political programs, the liberal wave has forced initially an unconditional and voluntary move towards the insertion of private capital in the facilities sector. In the different countries which underwent the ideological and political change especially after the decadence of the socialist ideas, the infrastructure were privatized independently from a more detailed economic analysis, even when economic discourses were brought in order to justify the change. This primarily ideological move may provoked some regulatory failures which were brought to light a decade later (see the rail privatization in the UK and the deregulation of urban public transport in Chile; in Brazil, this happened with the concession policy of the railways).

From the weakening of the liberal wave from the nineties on, eventual returns of social-democrat parties to power did not imply a switch to renationalize the facilities: the change had been internalized even by these parties, which abandoned nationalizing strategies in benefit of a more pragmatic attitude with respect to the roles of the State and of the private sector in the provision of the facilities: the more appropriated regulatory approach should be decided case-by-case.

This was the origin of the public-private partnership idea, which appropriated the PFI approach and some 
respective tools (project finance and value and risk analysis), but introduced an evaluation criterion for the comparison between the options of public and private provision, which is the Public Sector Comparator (PSC). By definition, this comparator aims to confront the results in terms of risk adjusted net present values between the options of traditional public provision and a determined alternative of private provision. On the basis of this indicator, different alternative arrangements for the participation of private capital and also the different concrete offers from the competing firms could be compared mutually, in order to select the one which is prospectively best value (Partnerships Victoria 2001, Treasury Taskforce s.d., PPP Knowledge Centre s.d.).

However, these apparently straightforward comparison and selection tools have been subject of acid criticisms. Firstly, where there are not actual options for a traditional public provision, whether because of lack of sufficient public financial resources or also of the too innovative character of the concrete project, whereby the public administration has not a record of any comparable experience, the comparator will lack of actual substance (Treasury Taskforce s.d.). Another issue is the lack of precision of the comparator and also its subjective character, which would allow all kind of manipulations.

But the main point is that the public sector comparator is far to serve as a peacemaker for the ideological and political struggle: the party which favors a stronger insertion of private investment will always argue that the comparator has a systematic pro-public bias. Beyond this, when for years and even decades public investment has been absent or too scarce, there would not be any trustworthy data for the comparison. Also the eventual value addition by innovations introduced by private investment would not be sufficiently taken in account. In principle, the best way to get valid comparisons would be to build up a really competitive partnership market, where the concrete offers by the private industry could be directly compare. But this would imply to go forward with the voluntarism pro-market policy, now with the argument that this would be the best way to get valid comparisons. On the opponent side, the pro-public party will argue that the PSC does not take in account the higher financial costs of the private option (The House of Commons, 2002).

In the battlefield of the regulatory policy we could point out as main actors the parties, the capital groups interested in the creation of new market opportunities (moreover their syndicates and association than the individual firms, which will play a stronger role in the further stages of the competition process), main officials of the public administration, and also academi- cians with some prestige.

Which analytical tools could help here? Beyond the traditional tools for the study of competition processes (e.g. value chain) we could point out the stakeholder analysis as well the more general contributions of the political sciences and of political sociology.

\subsection{Competition between projects (competition for their inclusion into the policy agenda)}

The selection of the concrete public investment projects to be gone forward with by the government takes place a long a very complex decision process, once different actors are involved here and since big values are at stake. The analysis of the multiple arenas occurring here has to adopt different levels.

Initially, we may propose a distinction between a macro-analytical level and a micro-analytical one. The macro-analytical approaches would deal with the general tensions between the broader categories of political, economic and social actors. At this level, the disputes between the political orientations and their respective programs come to the foreground, as the nature and character of the projects themselves reflect the ideologies, planning and regulation strategies and the project subjects which are preferred by the parties who are in power. Also the analysis of the competition between the major economic groups and their respective lobbies for the influence over the general government policies belongs hereto. The general mobilization of economic and social forces for their preferences is to be analyzed more deeply at this level.

At the micro-analytical level, the actions and attitudes of individuals and groups of individuals in order to have prevailed the projects of their preference are to be studied. In these actions, beyond the general interests of the social or economic category they represent, these individuals and groups are also seeking for personal interests and political self-promotion and particular financial out comings.

One could suppose, in this context, that each project has an electoral value (let us introduce for our aim the terminology vote ware). The production of such a vote ware which shall be politically efficient - or, in other words, to be capable to aggregate political, economic and social and also electoral forces - is not easy, given the special quality required for this product in terms of technical consistency and amount of interests to be benefited from it. Once an actor has matured such a vote ware, the competition process may lead to different attitudes and counter-strategies by his competitors: firstly, they would boycott the prospective proposal and try to impose their counter-project or simply to destroy politically the original proposal without any counterproposal (strategy of burning 
down of the competing fair box); secondly, they may appropriate themselves the prospective proposal and push away the original proponent (strategy of struggling for the ball); thirdly, they may try to ally with the original proponent in order to share its success and dividends (strategy of success at the shadow). At least, the competitor may adhere to the project, but try to interfere in its conduction, to change its aims and character during the course and after a period of collaboration try to take over the command and to oust the original proponent (strategy of ousting from the boat). It shall be stressed that this level of competition may occur between individual or group actors from a same party or association, as the prospective project may be used for their control over the political organization they belong to. This process may produce different types of interpersonal relationships, from the friendly collaboration to the openly inimical competition, going through different grades of "critical" collaboration, where the competing individuals and groups pretend a major technical, political or financial competence comparing to the incumbents. The different personal characters come here to the foreground, from the most aggressive to the more pacific, going through different grades of dissimulation.

The process itself of the political construction of a project, that is the process of aggregating stepwise political forces for its defense, deserves a more detailed analysis. The defendant party may use diverging tactics: firstly, it may consolidate it step-by-step until coming to the major decision-maker, going through several but relevant inferior stances (staircase tactics). The disadvantage of this prudent but slow process is that the competitors may have enough time to take preventive measures against its success. Alternatively, the proponent party may use the direct personal relationships with the major decision-maker, or by building up a broad alliance outside the government, preferably with politically influential economic and social forces which have direct access to the major decisionmaker in order to access him straightly, by-passing the different inferior and intermediary stances (heliport tactics). The by-passed stances may react with a violent fight against the proponent party, with hidden sabotage or with (friendly or "critical") adherence to the successful project. Mixed strategies (staircase with heliport) may be also considered in order to consolidate the project inside and outside the government before knocking on the door of the chief decider.

If we map this battlefield for a given project, different categories of actors come to the scene:

(1) First, the competition between the political parties, and within each of them, between groups and fractions and individual leading persons. Their struggle does not limit itself to the imposition of a vision for the society and for consequent government policies, but includes also the battle for concrete projects which reflect the programs. At the individual and group level, the aim is to self-promote internally and externally (in order to get a stronger position for the next elections), by means of proposals that aggregate political forces which eventually will obtain hegemony and will also be able to confront successfully competing proposals. These rival proposals may be contrary to the political orientation of the party first considered, but may even be compatible with its program, but as it has been presented by the rival party it will be fought by the first one. Alternatively, pure or "critical" adhesion may be a response of initially rival parties.

(2) Secondly, there is a competitive tension between different government resorts. Here the battle takes place between respective bureaucracies, which fight for that their projects will prevail in the government budget, even with prejudice to other resorts. Special aspects of this inter-resort battle are the fight for respective linked funds and the fight for the political prestige of some resort-linked corporations. Much of this battle is hidden, but there may be open conflicts with the Treasury, which tries to assure the consolidation of the public finances at the cost of the investments.

(3) The third competition level is generally known as lobbyism: here, different economic groups and their representative organizations try to get influence over the governmental budget. Sometimes, industry specific associations are created by governmental officials, especially if they refer to a determined public service. But these public service centered associations may aggregate also members outside the government. Inversely, associations that were created outside the government try to obtain adherence from governmental institutions or decisive personalities or also from councilors or parliamentary representatives by means of the creation of resort or industry specific forums or meetings. Sometimes, industry lobbyists may reinforce the opposition as a threat to a government that does not contemplate their interests. At this level, consultants and academicians may be involved.

(4) The social struggles by social groups and organizations outside the economic, political and social hegemonic field (neighborhood associations, NIMBY's, NGO's, environmental groups and the like) introduce a fourth competition arena with respect the governmental agenda and the respective projects. In a similar way to the lobbies of the major economic groups and the higher officials of the different government resorts, these movements are capable to articulate themselves in diverse forms with government officials and politicians, and may even ascend to 
higher position in Government or Parliament. Alliances between these non-hegemonic groups and established economic groups and parties are not uncommon, albeit some more radical claims have to be sacrificed or damped. The movements are, however, more used to resist to projects (especially infrastructure projects) than to propose alternatives. Most of their proposition focus on environmental and social policies, some of which bearing consequences for the broader industrial and economic policy. Within the movements divisions and dissents may occur, due to the struggle for power by some persons or groups, or due to divergent political points of view. Once again, academicians may play some role, helping to formulate and to consolidate the requests and programs.

(5) The regions and cities use to be in contest for programs, projects and budget resources in general. The rivalries that may arise between them can lead to fiscal wars which have to be controlled by the central financial authority. But they may join together in order to fight against or for policies, programs and projects of the central government. In this context, majors, governors and parliamentary representatives belonging to a same electoral constituency have a particular concern in giving account to their local electors, and this may lead them to collaborate or to compete between themselves, whereby this kind of relationship is also influenced by the competition between the political parties they belong to. This level of competition has given origin to different competition tools, e.g. urban, regional, and national marketing, which help the local government to analyze their weaknesses, potentials and opened opportunities and to develop competition strategies for attracting private investments. Within these strategies, the government may adopt industrial policies, e.g. industrial cluster plans and private governance policies, and attraction of key-industries. In the rule, major infrastructure projects (motorways, high-speed railways, but also ports and airports) are key elements in the regional competition strategy.

(6) The relationship between the statutory planning officials in Government and the lobbies and politicians is a next arena to be discussed. In general, the planning officials, with some support from the academia, try to assure long term rationality for the governmental action. This rationality may be however subject of invested interests and struggle for power by some individual or groups within government and the supporting consultancy firms and academics. Rivalries between consultancy firms and academia and within each of these categories may be also observed. Nevertheless, and independently from the actual reasons of the competing actors, the short term electoral needs of the politicians come here to the foreground and may conflict with long term targets and actions which have to be maintained along different administrative periods by the different administrations. Once in power, the political colligation (and the respective supporting economic groups) may impose changes and disruption of long term programs, as the planning officials are hierarchically subordinated to them. These "irrational" interventions of the politicians may generate frustration among the permanent government staff and a general dislike for politicians. Some part of the superior staff may, in the contrary, opportunistically adhere to the immediate interest that imposes the change, as a strategy for their own ascension or in order to avoid persecution and/or degradation in their career.

Inversely, the industry groups, mainly linked to the infrastructure sectors, need more stable rules and guidelines which are independent from the changes imposed by the political struggle. So they welcome agencies that are "independent" from these short term events and may firm alliance with politician who has the building up of such agencies on their own political and electoral agenda.

The more general planning issue has to be inserted into the context of this conflict between long term rationality and short term political dynamics. It may happen that the permanent government staff, allied with the academia, professional associations, social agents and even industries, succeed in passing through the Parliament Acts that assure a stronger planning discipline to Government. Deputies and even politicians inside the government may also reinforce this legislative act as they regard the new Planning Law as their own trophy which they will use in the electoral market as vote ware.

However, the passing through of the Act does not mean the definitive victory of the pro-planning party. When the government in power is interested in some projects that conflict with the current plans, they may force the staff to review the plans in order to accommodate the projects of their preference. Otherwise, at the moment the plans are being established, they may impose to the staff their projects as starting point for the Plan and its discourse (a sort of reverse planning).

Planning theory and history is a whole issue apart that deserves a deeper study in the context of the issue treated here, as they reflect this conflict between a long term rationality at the one side, which the permanent government staff stands for, allied with the academia and some social and economic actors, and, at the other side, determined politicians and industries, which try to impose their particular projects. The programmatic character of the party in government will influence decisively on the levels of power of each side, what will be a result of the competition level dis- 
cussed in section 2.1 above. Thus, conservative governments trend to sacrifice strategic planning in benefit of a "market approach", giving preference to actions that would foster private investments (Banister, 1994). Government with social-democratic orientation may reinforce the strategic planning, especially when they have a strong electoral support by the stable technocracy in Public Administration.

Evidently, the objectives and approaches within governmental planning itself may focus divergent priorities, as it may be more or less integrative, taking in account or simply disregarding, say, the insertion of transportation planning into a broader regional, urban and environmental policy, what is much reflected by the preferred analytical tools (COBA, Multicriteria Analysis, Value Engineering, etc.). Inside the technocracy, there may be tensions between groups that prefer a more resort centered approach, e.g., the construction of new road capacities decided on the basis of narrower cost-benefit analyses, and those who stress more integrative policies and analyses.

As the permanent staff trends to support and may even have vested interests in strategic long-term planning, the success of governmental long-term planning is in general dependent on whether there is a robust, stable and technically competent staff and on the relationships between this staff and the politicians. When the Public Administration is impoverished from such a staff by a deliberate policy with the aim to reduce the public sector in general, the planning idea and culture may lose much of its support, in benefit of a wilder competition between singular projects which are disconnected from a long-term strategy for local development.

In order to assure a better resort and political integration in the planning strategy and in the decision process, the government may set up permanent councils composed by representatives of different government resorts, industries and social groups or notorious personalities. By inserting some of the suggestions and also requests by these represented groups and personalities, the government may share with them the responsibilities (and risks) of his actions. These councils reinforce the image of "technical" or "social soundness" of the governmental action and decision, but may also convert themselves into a instrument of a lobbyism behind the doors in benefit of the invited actors and industries, in prejudice to the interests of the broader community, which is not represented, and also by-passing the parliament and elected local councils, which are at last the legitimate representatives of the society.

The general struggle for transparency and public participation interferes deeply into the competition process between the actors which are trying to impose their investment agendas. The restrictions on transparency and participation aim not only the unhindered execution of projects that may provoke reactions by negatively impacted social groups, impeding that these groups may organize themselves on time, but also to prevent that competing rival political and industrial groups may counterattack timely the prospective project put forward by the ruling groups and parties.

With respect to the proper methodological tools needed to analyze all these competition processes discussed in this section, it may remember that most of them occur behind closed doors. Therefore, deeper case history studies on the basis of documents, reportages and long and detailed interviews with people which have participated in them and also participative research methods are required in order to bring to light the facts. Game theory and stakeholder analysis are always remembered for similar research situation. Planning theory and tools themselves may have limit success, as they are instruments and weapons of technocratic discourse, therefore direct subjects and not methodological tools for the research envisaged here.

\subsection{Competition on the level of the selection of projects for the PPP program}

The competition for the selection of specific projects to be inserted into a PPP program is a very recent playfield and applies in countries where the government has decided to include regularly the partnerships into the toolbox for the investment programs. National and regional guidelines and handbooks on PPP consolidate the selection procedures, which is executed by a central PPP unit or directly by the cabinet. Some analytical evaluation tools (e.g. value and risk analysis) are used to select the projects, which in the rule have already to be part of the priorities of the current government policy.

Of course, the guidelines and handbooks will not make clear the actual selection process, as it can be expected that the respective political and economic stakeholders will not leave just to technocrats the decision power. However, in principle, the rejection of a project which is already a priority for the government policy for the inclusion into the PPP program does not mean that the government will drop the project, as it may be executed by other, more conventional funding means; nevertheless, the exclusion of the PPP program may be interpreted as a loss of prestige for its stakeholders. In this battlefield, the active actors are the government staff, the politicians, the stakeholder industries, consultants, academics which wish to have influence on the process and its procedures.

A peculiar modality of PPP that deserves a special discussion are the unsolicited proposals, by which a 
certain industry, duly assessed by consultants, brings forward to the government a project of its interest but that also fits to the governmental priorities. Accordingly to the handbooks, such a project would be subject to an analysis by the government staff, where the opportunity and quality should be tested. In the case of approval, the contract would be assigned by means of a peculiar procurement procedure, where the winner, if he is not the original proponent, would indemnify this one for the investments made for the preparation of the project. This partnership modality is a prospective issue for the research of competitive behavior in PPP projects, whereby the attitudes, strategies and actions of different actors (agents of the industries and of the government; politicians, consultants and also the academicians) and their mutual relationships are to be analyzed with respect to: (a) the preparation of the project; (b) the contact of the prospective governmental client; (c) the approval process by the government staff; (d) the composition of coalitions during the procurement phase and the preparation of counterattack measures against rival groups (alternatively, strategic alliances with them). The so-called negotiated procedures (without procurement) are also worthy of been analyzed, as in them these same competitive battles take place.

\subsection{Competition during procurement}

The procurement procedures have been considered by the literature as the main competition moment in industries with natural monopolistic characteristics, turning possible a competition for the market, as direct competition in the market may ruin the firms. However, even in these case competition does not limit itself to the procurement stage, as the contract may include some competitive incentives as benchmark or yardstick performance evaluation, incentive rewarding systems and, last but not least, competition by substitutes. The effectiveness of these incentive mechanisms have to be assured by legislation and the contract and to be controlled by the authorities.

Of course, the actual competition during the procurement stage and the life of the contract has to be analyzed more concretely. At a first moment, a project which has been at least provisionally selected to be included in the governmental PPP program (the definitive decision by the PPP Unit or by the cabinet to go on with procurement and contract assignment will still be given in the further stages) has to have its business case fully developed, whereby the government staff will have been assessed by consultants (which in their turn may have been selected or not by a separate procurement procedure). During this preparation stage, the staff enters in an intense dialogue with the "market" - prospective partners and their in- vestors/lenders and the respective associations -. Road shows, internet sites and direct visits are classical instrument of this preparatory dialogue. During the preparation stage, prospective competitors try to build up a narrower relationship with the government staff in order to obtain an eventual status of preferred bidder (see below).

At this moment occurs a sort of inverse competition, as the market sounding government is trying to sell its project in the national or even global PPP market. This moment deserves a watchful analysis, as the adhesion of investors to a given project may either simply result from its inherent quality, or rather from an obscure negotiation between the client management, constructors, supplying manufacturers, investors and even foreign governments and multilateral agencies. Once again, personal or group struggles for power within any of these entities may interfere in the final decision with respect to the proposed business, even if its financial profile does not comply with normal "bankability" criteria.

Once the adhesion of the "market" is assured as the feasibility and attractiveness of the project is demonstrated, one can expect that a competitive articulation takes place between coalitions of constructors, investors, suppliers and consultants, which will form the core of the consortia that will be present at the procurement. The behavior of individuals and groups in this articulation and their actual motivation (struggle for power, relationships and conflicts in the past) is worth of research. The coalitions may be project specific but also remaining for different procurement procedures for similar projects.

Often the government and its politicians have already preference for a determined consortium with which they have built up a relationship of mutual trust during the preparation of the project or for a long period before. Lasting mutual interests and supports (e.g. financial support during the elections) have also to be considered. In most of the countries such a relationship is regarded as corruption. But some countries admit that the public administration may have preferred bidders, but the preference has to be justified case by case on the basis of the required capacity and experience for the specific project, which must not be trusted to a broader set of unknown competitors, due to its high complexity and risk.

As a rule, a pre-selection procedure of the candidates, which are invited by an Expression of Interest announcement, takes place, and the final competitors are defined by objective criteria; sometimes, the number of qualified candidates to the further stages is fixed (e.g. only the five best classified may be invited to continue). In general, the pre-selection and the final selection procedure are executed by a commission 
which is composed by government staff or even by ("notorious") persons outside the Administration, whose actual behavior and relationships with the candidates are key issues for research.

Finally, the end selection of the chosen consortium takes place. This selection stage may have different modalities, which are often classified as open or restricted. In the open procedure, the final invitation to tender document and the draft contract are displayed to the candidates, which will have given sufficient time for the preparation of their proposals. When the selection takes place, the envelopes are opened simultaneously, and the proposals are compared on the basis of a previously defined criterion. The contract is awarded to the best placed. This procedure admits different iterative stages, dependent on the selection criterion adopted. For example, the proposals may be preliminarily classified for their quality or price (or combination of both), but the competitors may remake their offers in an auction-like procedure.

In the restricted modus, the draft tender invitation document and contract are redesigned accordingly to the pre-selected set of competitors and offered to a preliminary discussion with them, in order to incorporate their suggestions and proposed corrections. After this, the documents are consolidated and the competitors begin to prepare their proposals. Once the competitors return, the procedure may vary accordingly to the rules fixed in the legislation, the regulation or in the tender invitation document itself; sometimes, the commission may have a lot of discretionary power to determine the concrete procedure. Dependent on this power (which has to be admitted by Law), the commission may discuss each proposal openly or discretely with the respective competitor, and even suggest corrections or modifications which may add value to the contract. Different rounds of comparisons and modifications and also of classification and dropout of candidates may follow, until the commission comes to the final decision. This procedure may last longer than a year, but the legislation may limit drastically the scope of discretion of the commission in order to speed up the process, but at the cost that these restrictions may prejudice the contract value compared to a situation, where the commission may extract competitively the best value from the candidates.

Once the selection made, the final contract is signed after last negotiations made in order to optimize the contract, provided that the new and final contract value does not put in question the end classification of the competitors. After the contract is signed, another competition takes place which is the search for the final funders. If the contract is attractive enough, the funders may compete among them in order to participate at its financial package. But as infrastructure in- vestment is in the rule a highly risky affair, it is up to the contractor to go after banks and other investors, which will probably build up a financial consortium, which is often led by a public development bank or by a multilateral agency.

\subsection{Competition within the transportation market}

Especially green field infrastructure projects fit to the natural monopoly concept whereby competition may be ruinous. The high risks and the slow capital return require that market risks are significantly controlled in order that the foreseen cash flow, which is the core of the contract, may be assured the best possible.

In this context, the competition is basically limited to the procurement process, as discussed before. However, the transport market is always permeable to journey options which put in question the pretended market protection assured by contract. A first challenge to the protection is put by the feeder lines. In general, these are inserted into the contract subject in order to be operated by the private partners or to be subcontracted by them to other operators. Alternatively, they may be conceded by the Authorities to a third party, but in a way to assure that they are at least operationally submitted to the main operator, with whom they have to sign operational contracts which establish the lines, frequencies, fare prices, shares of the fare box receipts and other measures in order to assure a common image of the integrated service network. The degree of submission of the subcontracted or sub concessionary operators is a central issue for determining the actual control of the market by the main concessionary.

However, unless the main concessionary acquires by contract the operation or the operational and commercial control over the whole network in the city or in the region, or unless the government represses successfully all services which will menace the contracted cash flow, always there will be services, whether feeder, complementary or direct competing, which may put the protection in question. These services may be regular or charter or even illegal, which are common in countries where the public administration is not able to repress effectively the "informal" industry. At last, taxis, paratransit taxis, individual transport by car, bike or walking may be alternatives for the user that is not willing to submit himself to the rules of the contracted monopoly.

\subsection{Competition for the positive impacts deriving from the investment}

The rise of land value in the proximities of the new system is the last competition level to be discussed here. At this moment, the government tries to regain at least part of the benefits deriving from his direct in- 
vestments by adjusting the fiscal values, imposing taxes on the especially benefited neighborhoods or by other financial means authorized by Planning Law. Equally, the investors may be additionally rewarded with areas and real estate adjacent to the new infrastructure, in order that its added value is inserted into the cash flow or into the set of financial risk mitigation measures. However, third parties (real estate investors, manufacturing industry, commercial and service sector, etc.) may anticipate themselves to the investment, buying land for a still not adjusted price, as soon they get notice from a project that may raise land values.

\section{CASE STUDY: THE LONG PATH TO TRANSMILLENIUM}

Mayor Peñalosa's struggle for a transit oriented transportation policy for Colombia's capital city Bogotá started in 1975, when he accompanied his father's work as the chairman of the Habitat Conference. On his election for city councilor in 1988 he brought in this event. But in these very years the President reinforced the liberal economic policy and opened the internal market to the import of vehicles. The artisan transit services by minibuses flourished, worsening the congestion in the streets of the cities. A contracted study by JICA stressed the development of several transportation axes, without establishing clear directives for a public transport policy. The construction of a metro system was then considered as the definitive solution and put forward by President Samper, who was ready to dedicate special financial help to the capital, provided that the metro solution was adopted. In 1998, Penãlosa was finally elected as Mayor and tried immediately to raise the fuel tax. But his preference for the transit policy was a modern bus corridor, as it would be much more cost effective and be within the limits of the municipal resources. For political reasons, the new President Pestrana insisted on the metro solution and Peñalosa accepted this condition to get the resources from the central government.

But with part of these resources the Mayor invested into studies for a modern bus corridor option and begun a hard struggle with the National Parliament, in order to get the authorization to invest the resources dedicated for the metro solution in the corridor solution. As Peñalosa's mandate was already midterm, he decided to use directly the municipal resources for the first stage of the project, whereas the national resources would be used in the second stage.

Peñalosa's corridor concept was a Curitiba-like corridor, differing radically from already current proposal to build a corridor for the current minibus operators. For its design, international consultancy was con- tracted, but hard political struggles for the choice of the most appropriated routes had to be fought, as councilors tied to the minibus operators and associations tried to reserve the main avenues for the traditional transport service, shifting the new system to relatively inaccessible axes.

Beyond this, the concept included broad urban renewal measures in favor of the poor, as a whole network of bikeways and walkways which was integrated into the corridor concept. Social equipment as parks, culture and sport centers were also on the program.

The construction of the transit system and of the connected social equipments has also suffered different interruptions due to the expropriation and transfer of public infrastructure and equipment, which provoked hidden political resistance from incumbent officials and politicians. But the hiring of competent and energetic project managers assured the final victory over these hindrances. The construction work was executed by a public corporation, the Institute for Urban Development. In 1998, the bus models were presented to the public, which provoked some negative reactions from the minibus operators.

Evidently, the Transmillenium concept would imply in a major organizational change, as larger buses should be acquired. Initial ideas to concede the whole system to a sole operator were soon dropped, as the resistance of the army of small operators and of the respective associations and unions would be impeditive. A master convincing procedure was put into operation, and several associations began to reorganize themselves into major operators, whose equities were owned by the traditional ones. Nevertheless, rebellions, strikes and street blockades were in the order of the day, as the deadline for the inauguration of the system neared. The conflicts worsened and some extreme-right paramilitary groups menaced to assassinate the leaders of the rebellious groups, which would imply a political disaster for the project.

Once in operation, the overwhelming success led the municipality in celebrating in 2003 an extended agreement with the National Parliament, which assured a generous funding line in order to build up a $388 \mathrm{~km}$ long network of similar bus corridors until 2016. Peñalosa's successor and straight collaborator Mockus was elected Mayor in 2003, assuring the continuity of the project.

The most dangerous menace to the project is still the remaining operators which were not integrated into the Transmillenium companies. Some of them and their associations are trying to implement parallel “quality” networks. (Gómez, s.d.; Celis, s.d.) 


\section{FINAL COMMENTS AND PROPOSITIONS}

In the present contribution, a sequence of competitive processes has been sketched which occur along the execution of an infrastructure project for land passenger transportation by means of a public-private partnership. As explained and exemplified, the competition process in such projects is not straightforward, but decomposes itself in different competition moments, namely: the competition for the regulatory policy; the competition for the inclusion of a determined project into the governmental agenda; the competition for the inclusion of this same projects into the PPP program; the competition for the finalization of the specifications of the project by consultants (not discussed here); the competition for the contract; the competition in the transportation market; and also the competition for the benefits of the new infrastructure. At each of these stages, different range of actors, both from the public administration and from the private sector, are present.

In the presently developed framework some hypothesis are put on competition: to start with, there is a competition for governmental projects where actors from a political scene utilizes them as vote ware; thus, these projects are far more than a simple subject of public policy, which may be derived from its general goals and targets and from the governmental strategic planning, accordingly to the political orientation of the ruling party. This absolute need for vote ware by politicians, and also the general class interests of major economic groups, put in question the logic of the long-term strategic planning as defended by most of the permanent government staff. Consequently, single projects may be more important for the vote ware seeking politicians than the strategic planning for a whole policy, as they are pre-conditioned for the electoral process, on which their professional careers depend vitally. This behavior may also be observed at some government officials, which need equally projects for demonstrating their administrative capacity (that is, they need also some sort of vote ware in order to proceed in their bureaucratic careers, as the elected decision-makers vote in their turn for their main assessors).

To ignore this competition mechanism and this tension between long-term planning needs a short-term demand for (electoral and administrative) a successful produce, as it has always produced a serial of frustrations for those who defend a more long-term rational approach for public policies. May the strategic planning discourse serve well for the long-term needs of society, it must not be overseen that this discourse has also to satisfy the short-term capacity demonstration of those who are elected by the democratic process in order to decide the actions of the public administra- tion.

The recognition of these facts does not imply that the battle for long-term policies and planning on behalf of a sustainable development is lost. But the efforts of those who stand for long-term and sustainable policies must produce on time projects that are both compatible with a long-term vision and a short-term demonstration effect and may aggregate political, economic and social interests, in order that a ruinous competition between projects is damped. A possible solution for this challenge would be the adoption of major synthesis projects which satisfy these apparently irreconcilable needs. These synthesis projects, e.g. a major infrastructure project, shall be inserted to a long-term sustainable vision for the regional development and a whole set of multi-sector, social and economic policies which complement the infrastructure project, in order that this may produce the highest general benefit to the region.

Once an infrastructure project is realized as vote ware for the decision-maker and a market opportunity for the economic groups, it has to be protected from the general market competition, given the high investment risks involved. Evidently, this protection will put restrictions on the free competition in the infrastructure market.

This one aspect turns necessary some last comments on collaboration, which contra poses competition. If competitive relationships are generally observed between different actors at different stages of decision and action, these relationships co-exist with collaboration, without which no competition is feasible at strategic level, especially in major projects. This collaboration may come into effect in different manners, from compulsory collaboration (direct and even dictatorial subordination) until the free co-operation, going through different forms of fostered collaboration, whether by threats or by premiums in different degrees.

In the case of public-private partnerships for infrastructure projects, the collaboration between the public and the private sectors (which has always existed in different forms, even in the social and industrial policies) is the very starting point, albeit the different decision approaches and aims of these two actors. It has to be remembered that PPP projects are direct subject of public policies, may they also produce profit for the private industry. This collaboration does not limit itself to the public and private actors immediately involved, but also with the larger public, as its acceptation is pre-condition for the political stability of the project. Once the project is decided, the construction of consortia between different firms of different industries is a major moment of collaboration. Collaboration also exists between the government of- 
ficials and the actors of the consortium, once the contract comes to effect, with the aim that the project may succeed. The necessary market protection is also of collaborative attitude of the government towards his private partner. Finally, feeder service will collaborate with the main concessionary. One may conclude thus that competition has to be studied together with cooperation and collaboration.

Summarizing all these considerations and the exposed framework, how shall they be dealt with by research? The panorama explained by this contribution opens up different investigation levels on competitive (and collaborative) behaviors before, during and after the execution of infrastructure projects by publicprivate partnerships on the field of passenger land transport. A research program in this sense would have the following core themes:

a. The mapping of competition and collaboration moments at the execution of infrastructure projects;

b. The mapping of the respective actors and their competitive and alliance strategies;

c. The mapping of analytical tools existing and to be developed in order to study the mapped phenomena;

d. The observation of introduction of forms of public-private partnerships on the field of infrastructure investment for land passenger transport;

e. The study of cases to be selected: these are most needed for the construction of the general framework proposed here and for the study of the different competition stages and their mutual integration. A project that achieves to be executed, may it ever be distant from the initial purposes and targets, is a survivor of a whole set of perils. The analysis of its victorious path (and also of the history of the projects that were defeated in different stages) will bring to light the logics present in the different stages and also their continuous integration.

We may conclude this contribution pointing out the limitations for its development and the precarious character of the sentences, as its main purpose has been to begin a discussion in order to plan a more systematic and cooperative research effort on this theme.

\section{REFERENCES}

Banister, D. (1994) Transport Planning. London, E \& FN Spoon.

Celis, F. C. (s.d) De los Empresarios del Transporte Colectivo para una Nueva Ciudad. Bogota, Alianza Tránsfer.

Gómez, J. (s.d.) Transmillenium. La Joya de Bogotá. Bogotá, Transmilenio S.A.

HM Treasury (2000) Public Private Partnerships: the Government's Approach. London, The Stationery Office

The House of Commons (2001) The Private Finance Initiative (PFI). Research Paper 01/117. London: House of Commons Library
Nash, C. and Walter, J. (2005) Competition and Regulation: Theme B. In Hensher, D. (ed.) Competition and Ownership in Land Passenger Transport. Selected Refereed Papers from the 8th International Conference (Thredbo 8). Oxford, Elsevier.

Partnerships Victoria (2001) Public Sector Comparator. Technical Note. Melbourne, Department of Treasury and Finance of the State of Victoria.

Porter, M. (1998) On Competition. Boston, Harvard Business School Press.

PPP Knowledge Centre (s.d.) Public Sector Comparator. The Hague, Ministry of Finance.

Preston, J. (2005) The Road to Rio: A Brief History of the International Conferences on Competition and Ownership in Land Passenger Transport. In Hensher, D. (ed.) Competition and Ownership in Land Passenger Transport. Selected Refereed Papers from the 8th International Conference (Thredbo 8). Oxford, Elsevier.

Treasury Taskforce (s.d.) How to Construct a Public Sector Comparator. Private Finance Technical Note No. 5. London, HM Treasury. 